\section{Visión Electrónica Más que un estado sólido \\ https://doi.org/10.14483/issn.2248-4728}

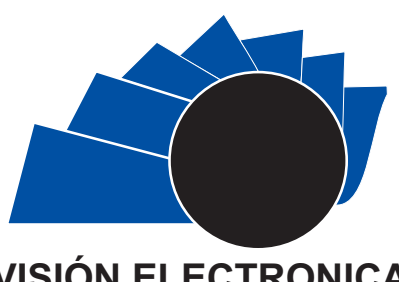

VISIÓN ELECTRONICA

\title{
Usaquén small hydropower plant - successful case
}

\author{
Pequeña central hidroeléctrica Usaquén - caso de éxito \\ Diego Fernando Rodríguez-Galán ${ }^{1}$, Andrés Escobar-Díaz²
}

\section{INFORMACIÓN DEL ARTICULO}

Historia del articulo

Enviado: 10/11/2018

Recibido: 04/12/2018

Aceptado: 18/12/2018

\section{Keywords:}

Hydraulic systems, Hydroelectric power generation, Power generation control,

Pressure control,

Turbogenerators,

Turbomachinery.

\section{Palabras clave:}

Sistemas hidráulicos

Generación hidroeléctrica

Control de generación de energía

Control de presión

Turbogeneradores

Turbomaquinaria

\section{ABSTRACT}

In this study a presentation is made of the Small Hydroelectric Power Plant (PCH) located in Usaquén (Bogota), the work is based on an engineering project carried out by the Aqueduct and Sewer Company of Bogotá (EAAB). It is addressed first of all the environmental problems considered in this project and the business context that propitiates it, taking into account the technical background of the operation of the aqueduct system of the city. In second instance, the technical generalities and the scopes that were estimated in the formulation of the project are exposed to finally contrast them with the results obtained after five years of operation of the project.

RESUMEN:

En este estudio se hace una presentación de la Pequeña Central Hidroeléctrica $(\mathrm{PCH})$ situada en Usaquén (Bogotá), el trabajo se basa en un proyecto de ingeniería realizado por la Empresa de Acueducto y Alcantarillado de Bogotá (EAAB). Se aborda primero que todo la problemática ambiental considerada en este proyecto y el contexto empresarial que lo propicia, teniendo en cuenta los antecedentes técnicos de la operación del sistema de acueducto de la ciudad. En segunda instancia, se exponen las generalidades técnicas y los alcances que se estimaron en la formulación del proyecto para finalmente contrastarlos con los resultados obtenidos luego de cinco años de operación del proyecto.

\footnotetext{
'BSc. In Control Engineering, Universidad Distrital Francisco José de Caldas, Colombia. Current position: Empresa de Acueducto y Alcantarillado de Bogotá, Colombia. E-mail: dfrodriguez@acueducto.com.co. ORCID: https://orcid.org/0000-0002-1936-001X.

${ }^{2}$ BSc. In Electronic Engineering, Universidad Distrital Francisco José de Caldas, Colombia. MSc. In Electronic Engineering, Universidad de los Andes, Colombia. MBA, Universidad de los Andes, Colombia. Current position: Assistant professor at Universidad Distrital Francisco José de Caldas, Colombia. E-mail: aescobard@udistrital.edu.co. ORCID: https://orcid.org/0000-0003-0527-8776.

Cite this article as: D. F. Rodríguez-Galán and A. Escobar-Díaz, "Usaquén small hydropower plant - successful case", Visión electrónica, algo más que un estado sólido, vol. 1, no. 2 , Special edition, july-december 2018. DOI revista: https://doi.org/10.14483/issn.2248-4728 


\section{Introduction}

The aqueduct system of Bogotá City has been divided into macro service zones according to its topographical characteristics, so it is necessary to regulate the flows and pressures to guarantee the service conditions, these regulations are generally made with valves wasting the hydraulic energy. In 2010, the EAAB proposed the possibility of taking advantage of the hydraulic energy dissipated in the Usaquén Pressure Regulatory Structure (PRS), through a small-scale power generation project (capacity less than 15 MW) by building a Small Hydropower Plant (HPP). With a net head of 71.5 mca and a flow of $2.85 \mathrm{~m}^{3} / \mathrm{s}$ for a capacity of $1.8 \mathrm{MW}$, the generation of $12 \mathrm{GWh}$ /year was projected in the Usaquén HPP, representing additional earnings for the company.

Moreover, this type of projects is considered by the United Nations as Clean Development Mechanisms (CDM) for its positive environmental impact by mitigating emissions of Greenhouse Gases (GHG) being able to generate additional earnings through the attainment and sale of Certifified Emission Reductions (CER), bonuses that were established in the Kyoto Protocol (KP) as part of the international agreement of the United Nations Framework Convention on Climate Change (UNFCCC).

\section{Context}

\subsection{Environmental}

Human activities have generated a progressive increase of $\mathrm{GHG}$ in the atmosphere, in fact, global energy demand has increased close to $150 \%$ between 1971 and 2015 depending mainly on fossil fuels, increasing $\mathrm{CO}_{2}$ emissions and accelerating global warming. Figure 1 shows how the use of energy constitutes the human activity that produces the greatest amount of GHG emissions, with $\mathrm{CO}_{2}$ being the most representative with $90 \%[1]$.

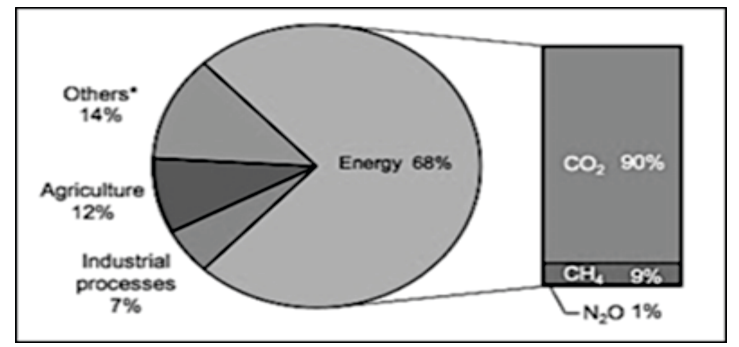

Figure 1. Global estimation of GEI emissions on $2014[1]$.

The problem of climate changing was recognized as a real fact at the United Nations Conference on Environment and Development held in 1992, The first addition to the UNFCCC international treaty, the KP, was approved in 1997 committing the industrialized countries to stabilize GHG emissions, therefore, it has moved the governments to establish laws and policies to fulfill their commitments and has led to the creation of the carbon market [2-4]. To involve countries without formal reduction commitments, the PK proposes the CDM, which aims to facilitate the cost-effective achievement of goals, allowing countries with commitments, the purchase of CERs, obtained through projects for reduction of emissions of carbon fixation carried out at developing countries [2-6].

Even so, there are few incentives to invest in renewable energy sources and the scarce contribution to the profitability of projects based on the mechanisms that currently operate, has caused an increase in generation levels with fossil sources, which generate greater pollution by emissions $[1,7]$. The developed countries have been considered as the generators of most of the GHG, however, recently the developing ones have surpassed the emission levels of the industrialized countries, because of it the 2015 Paris Agreement expands mitigation obligations to all countries regardless of their level of industrialization [1].

While it is true that Colombia has one of the lowest GHG emission rates (less than $0.4 \%$ of global emissions), climate change affects the country in a considerable way. To counteract this scenario, in the country there is a growing wave of projects in fields such as transport, generation and efficient distribution of energy, solid waste management, wastewater treatment and forestry activities [6]. For these projects to be cataloged as CDM they must be approved by the Ministerio de Ambiente y Desarrollo Sostenible (MADS), a designated national authority that registers the Colombian companies that have formulated and implemented CDM projects in these fields, and then promotes them to the international community $[3,5,6$, 8].

The EAAB has been established as the first Colombian public company to formulate and implement small scale renewable energy CDM projects, obtaining CERs. The EAAB has three HPPs: Santa Ana, Suba and Usaquén, plus another one in projection called Ventana $[5,9,10]$, the energy generated in these HPPs helps to mitigate climate change by reducing GHG emissions by displacing the use of thermoelectric plants in the National Interconnected System, because hydroelectric generation projects have priority of dispatch in the network $[9,11]$. The sale price of these certificates is a function of the reduction committed in terms of tons of carbon dioxide equivalent ( $\mathrm{tCO} 2 \mathrm{eq}$ ) and of the price per reduced ton paid in the emission markets [7]. 


\subsection{Legal}

It is also important to mention that through Law 164 of 1994 the UNFCCC was approved [12] and through Law 629 of 2000, Colombia ratified the KP [13], allowing the country to participate with CDM projects [5]. The institutional strategy to promote the incursion of Colombia into the international market of verified GHG reductions was presented in CONPES document 3242 of 2003 [14]. Through Resolution 0340 of 2005, the MADS established the Climate Change Mitigation Group with the function of supporting the implementation of policies regarding the mitigation of climate change and promoting the marketing of CERs [15] and established the procedure for national approval of projects to reduce $\mathrm{GHG}$ emissions that opt for the CDM through Resolution 2734 of 2010, repealing Resolution 0551 of 2009, which in turn repeals Resolution 0453 of 2004 [16]. Similarly, the Secretaria Distrital de Ambiente formed the Group on Climate Change through Resolution 6524 of $2011[17]$.

\subsection{Business}

Furthermore, the aqueduct system of Bogotá City is composed mainly by three subsystems: 1. Supplying: responsible for the collection and treatment of water; 2 . Driving: responsible for water transport through matrix networks; and 3. Distribution: which delivers the water to the users of the service through smaller networks [18], as illustrated in Figure 2. Water flows and pressures caused by the differences in elevation between the storage and distribution tanks at the different service zones are controlled in the matrix network, usually by means of PRS with the consequent waste of energy [18, 19]. This condition has allowed the $\mathrm{EAAB}$ to conceive the possibility of using this energy through HPPs parallel to the PRS, which can generate electricity without affecting the service normally provided to the city, thus obtaining additional economic benefits as well as contributing to the replacement from polluting sources of power generation [20,21].

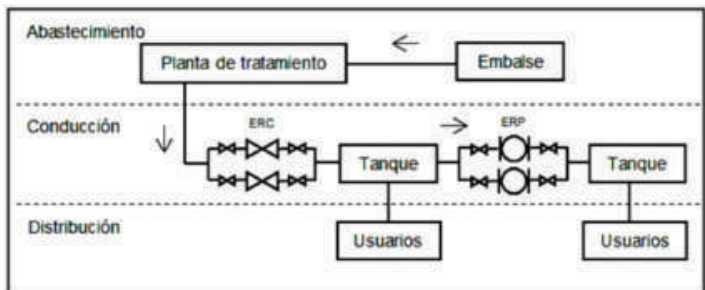

Figure 2. Main aqueduct system components. Source: own.
As a operation point of the city's potable water distribution system, the general operation of the HPP is in charge of the Gerencia Corporativa del Sistema Maestro through the Dirección Red Matriz Acueducto, while the technical and commercial operation related to the process of generation and sale of electrical energy is responsibility of the Gerencia Corporativa de Tecnología, through the Dirección Servicios de Electromecánica, who also provide electrical, electronic and mechanical maintenance. The Gerencia Corporativa Ambiental is responsible for monitoring the CDM component [22].

\section{Background}

\subsection{Santa Ana HPP}

At Santa Ana HPP, it is possible to generate 40 $\mathrm{MWh} /$ year with a turbinable flows of $7.5 \mathrm{~m}^{3} / \mathrm{s}[9]$. In addition to the earnings from the sale of electricity, in 2008 the first two issues of CERs were sold with a price of $€ 16.25$ each, receiving incoming of $\$ 517,835,534$ from the sale of $11,096 \mathrm{CERs}$ and $\$ 1,111,819,338$ for the sale of 23,403 CERs [11], situation that consolidated the idea of executing this project in Usaquén.

\subsection{Usaquén Pumping station and PRS}

Originally conceived as a pumping shown in Figure 3, the Usaquén station propelled the water from the Tibitóc Plant to the lower south zone and the intermediate zone. However, with the entry into operation of the Chingaza system, the station was reconfigured as PRS without affecting the pumping infrastructure, which got out of service. Figure 4 shows the pressure reducing valves corresponding to the low south and low nor thern zones, where the pressure drops from 120 mca to 43 mca and 53 mca respectively.

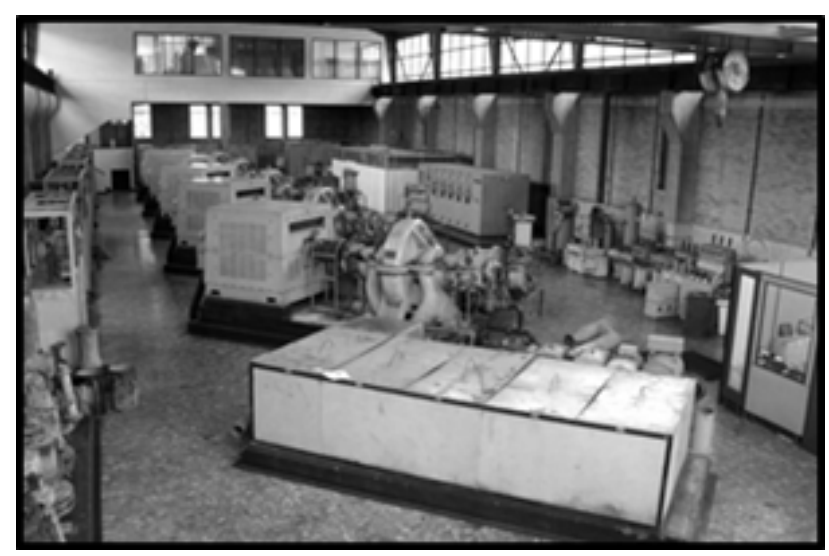

Figure 3. Usaquén Pumping Station [21]. 


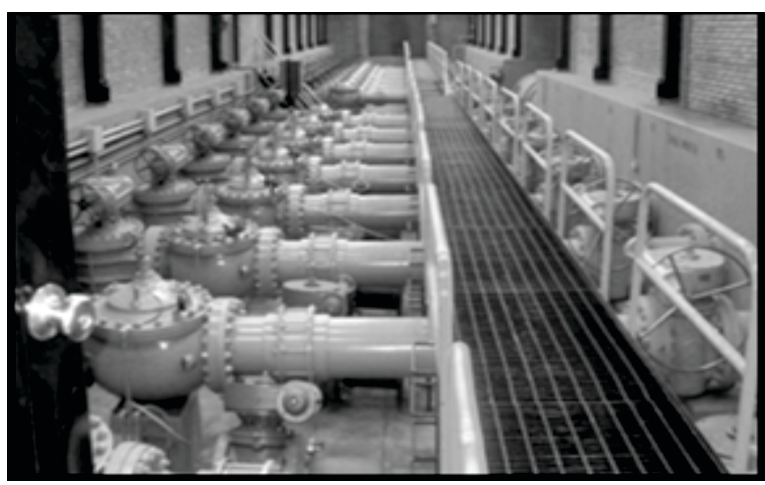

Figure 4. Usaquén PRS Valves [21].

\section{Technical Aspects of the Project}

Studies were carried out for the analysis of the technical and economic feasibility of the project, which included: topography, geodesy, geology, geotechnical, hydraulic, structural, environmental and energetic components. After evaluating the options with their affectations and risks, the feasibility and convenience of installing the HPP in the pump house was verified so that it is parallel to the PRS of the southern low zone, as shown in Figure 5 , where the location of the HPP is marked with a box that is detailed in Figure 6.

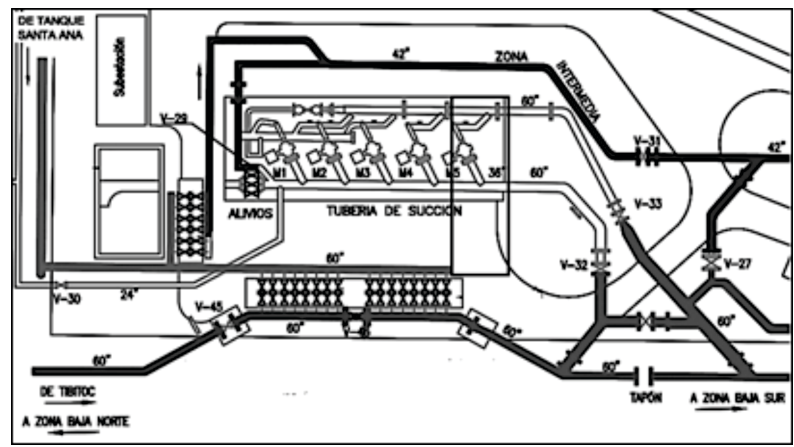

Figure 5. Usaquén Station [18].

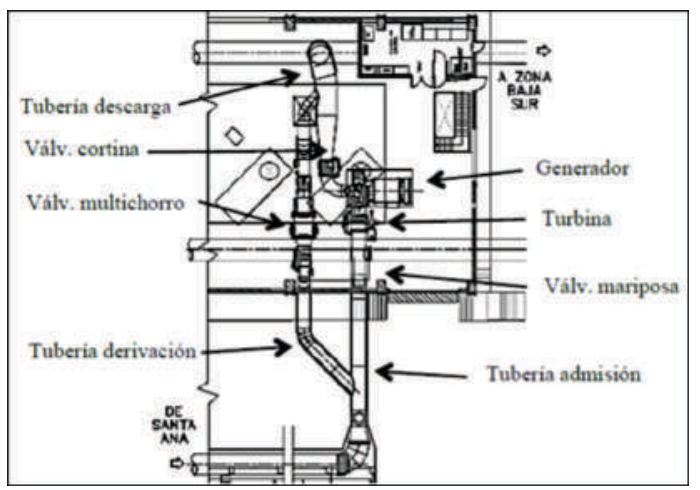

Figure 6. Usaquén HPP [23].
The definition of the capacity of the Usaquén HPP was oriented to the analysis of the hydraulic energy available in the reduction station of the southern low zone. The design flows depend on the historical flows and the current growth of the demand of the sector that is supplied through this area, that is, it depends on parameters such as population growth, consumption habits, trends or changes in land use and the cost of the service, among others. Due to the above, the demand for water presents a uniform and characteristic behavior, linked to the weather and the habits of the population. $[20,21]$.

\subsection{Flow and Pressure Variation}

As a matter of fact, historically, the behavior of supply and demand for water in Bogotá has been affected by factors such as economic crises, tariff increases (Law 142 of 1994), policies for the rational use of water (Law 373 of 1997), control of unaccounted water and the emergency supply in the Chingaza system (1997), factors that are evidenced in Figure 7. Faced with the uncertainty of the demand growth in the sector, it was proposed that the design flow be associated with the daily variation of the historical flows and the time variation for the design of the best performance turbine $[20,21]$.

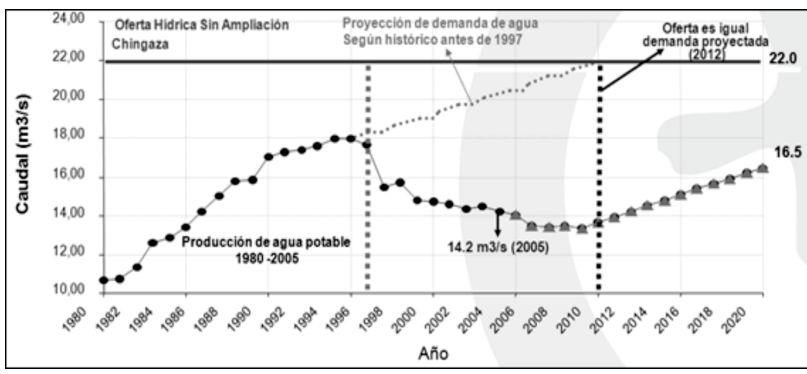

Figure 7. Hidrical offer and demand behavior at Bogotá City [20].

For the capacity analysis of the HPP, the dynamic flow behavior and the inlet and outlet pressures were studied, establishing their daily and hourly trends during a sampling period of 6 months, that is, a period of high and low consumption according to the annual trends, generating a series of representative records for the system model [20, 21]. Figure 8, shows the average variability of the flow in the 24 hours while in Figure 9 the hourly variation of pressures in one day is presented: in the upper part the input pressure record (120 mca) is presented while in the lower part the outlet pressure record is shown (42 mca). 


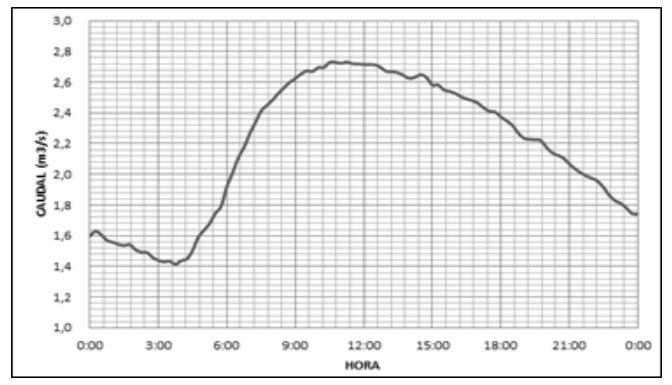

Figure 8. Hourly Mean Variation of Daily Flow [20].

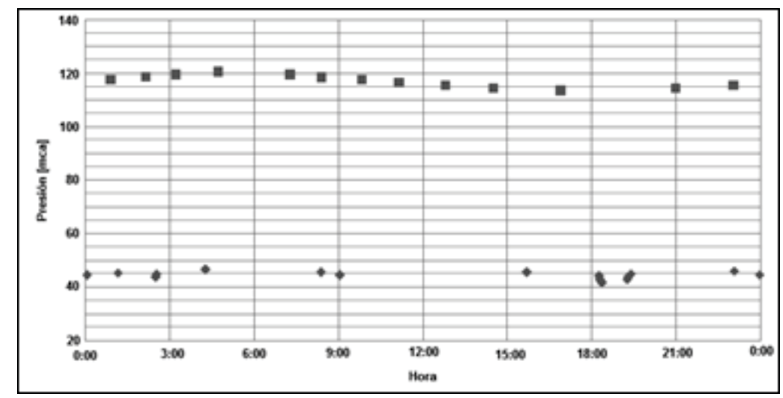

Figure 9. Hourly Mean Pressure of Input and Output [20].

\subsection{Power and Energy}

The study of power and energy showed that the maximum capacity of the HPP is $2.0 \mathrm{MW}$, however the inflection point in the generation of energy is reached at 1.8 MW, with a projected generation of 12.04 GWh/year as observed in Figure 10, [20]. From 1.8 MW the energy is not increased because the turbine works with lower efficiencies and the flow records above the design flow are not enough to overcome the loss of efficiency. The design flow and the net head for the 1.8 MW capacity were established at $2.85 \mathrm{~m} 3 / \mathrm{s}$ and 71.5 mca respectively [20].

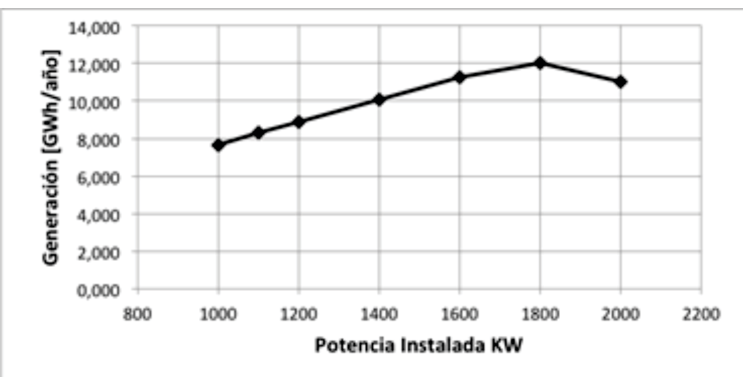

Figure 10. Annual generation projected by capacity [20].

\subsection{Efficiency}

Once the flow and the net head were defined, the potentially installable capacity was calculated as the product of the flow, the net head, the gravity and the efficiencies of the turbine, the generator and the transmission to the electric network [20, 21]. According to manufacturers, it is not recommended to operate below $80 \%$ of efficiency or below $40 \%$ of power. Figure 11, represents the efficiency graph of the turbine and the generator used for the evaluation of energy. Table 1, details the efficiency of electromechanical equipment according to the manufacturer's and supplier's data [21].

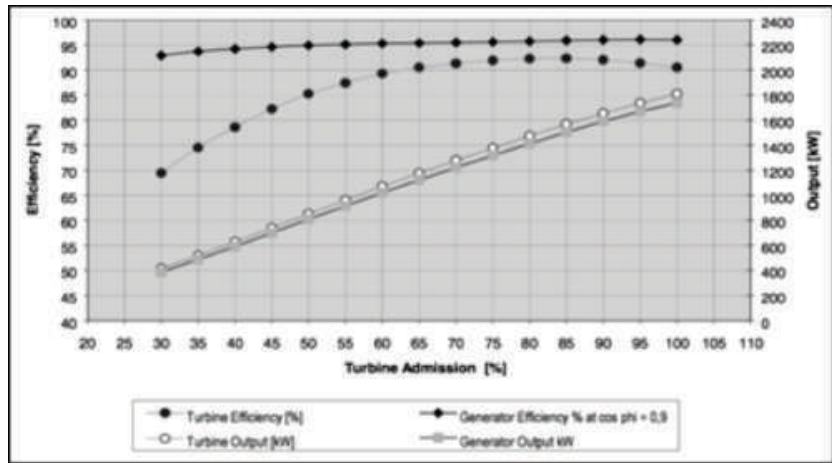

Figure 11. Efficiency of the turbine and the generator [24].

\begin{tabular}{|l|l|}
\hline \multicolumn{1}{|c|}{ Element } & Efficiency [\%] \\
\hline Fully loaded turbine & 90,50 \\
\hline Fully loaded generator & 96,00 \\
\hline Fully loaded transformer $(\mathrm{PF}=0,9)$ & 98,80 \\
\hline Connectivity to Codensa & 99,98 \\
\hline Global at Codensa entry & 85,86 \\
\hline
\end{tabular}

Table 1. Electrical efficiency [21].

\section{Design}

The project started on March 1, 2010 and entered into commercial operation on April 15, 2013, being developed in 6 phases: 1 . Study of capacity according to hydraulic analysis (usable flow and pressure) and economic analysis (maximum net present value), 2. Advanced study of technical and economic feasibility, 3. Detailed design (civil, mechanical, electrical, electronic), 4. Construction of civil works, 5. Supply, assembly and testing of equipment (mechanical, electrical and electronic), 6. Operation of the HPP for one year (trial period) [23]. 


\subsection{Mechanical Component}

Taking into account the limits for the selection of turbines established in Figure 12, and given the conditions of flow and pressure, the Francis turbine shown at Figure 13 was chosen. The Usaquén HPP feeds from the Santa Ana tank through a 60 inch diameter and 1,603 $\mathrm{m}$ in length pipeline matching with the hydraulically operated butterfly valve illustrated in Figure 14. Through the gate valve with electric actuator that is observed in the Figure 15, the flow is discharged to the Parque National and Santa Lucia tanks to finally be distributed to the users. Additionally, when the turbogenerator is turned off the flow is bypassed through the multijet valve of Figure 16, guaranteeing the service pressure.

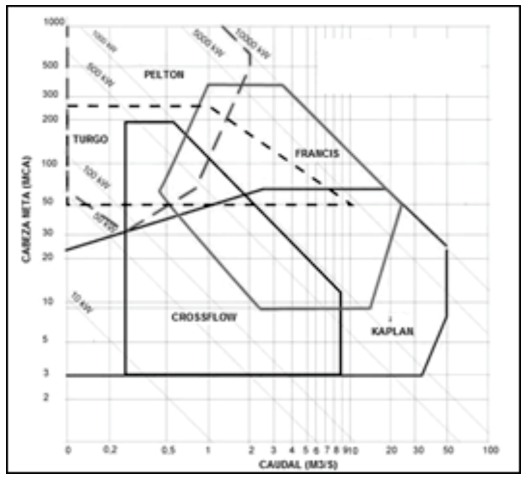

Figure 12. Hydro turbines selection limits [19, 25].

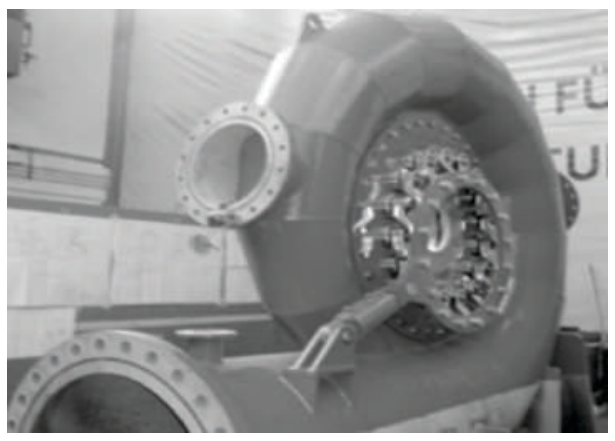

Figure 13. Francis Turbine for the Usaquén HPP [24].

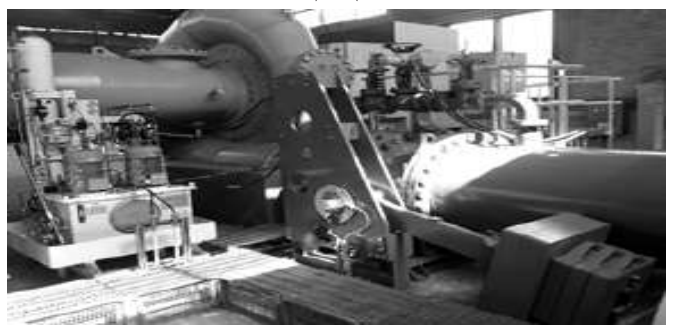

Figure 14. Admission pipe and butterfly valve. Source: own.

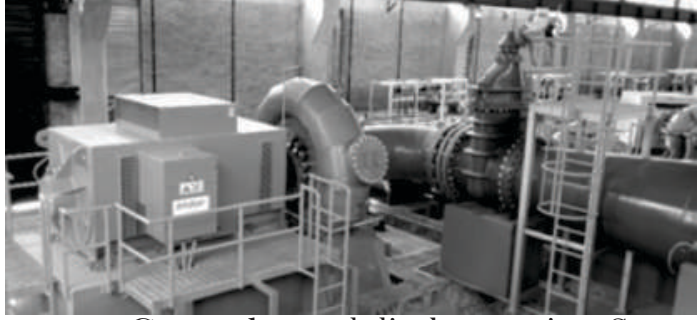

Figure 15. Gate valve and discharge pipe. Source: own.

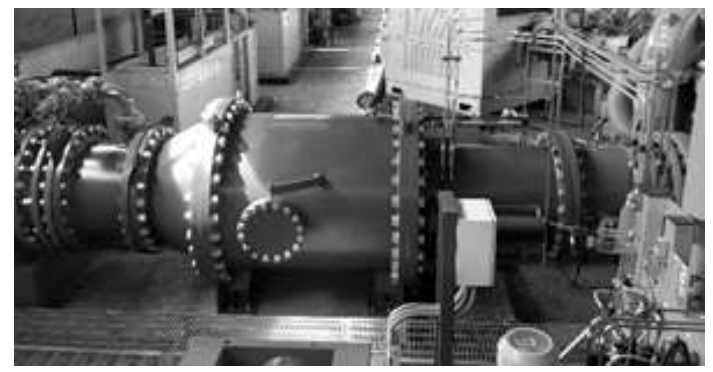

Figure 16. Multijet valve for turbine bypass. Source: own.

\subsection{Electrical Component}

The generator is synchronous horizontal brushless of 10 poles, with star connection and capacity of 1,930 $\mathrm{kVA}$ to $11.4 \mathrm{kV}$. Its nominal speed is $720 \mathrm{rpm}$ and the runaway speed is 1,221 rpm [23].

\subsection{Electronical Component}

The process has the necessary instrumentation for hydraulic, electrical and auxiliary variables which are acquired by the PLC, published in the local Human Machine Interface (HMI) shown in Figure 17 and transmitted via radio to the servers of the EAAB Control Center for deployment in the modern Supervision, Control and Data Acquisition (SCADA) WinCC shown in Figure 18.

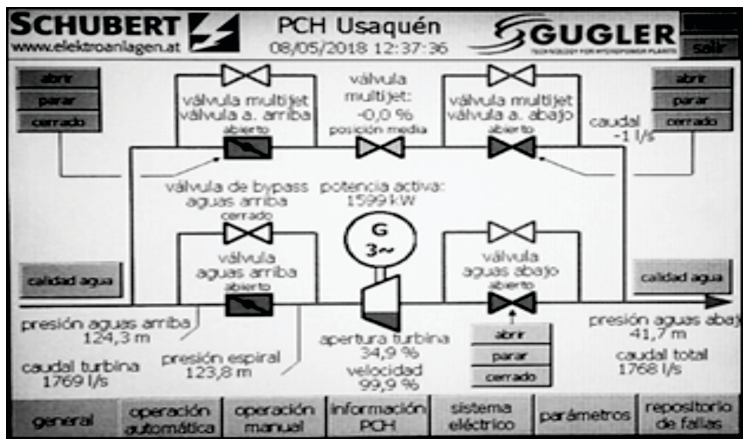

Figure 17. HMI screen at operation room. Source: own. 


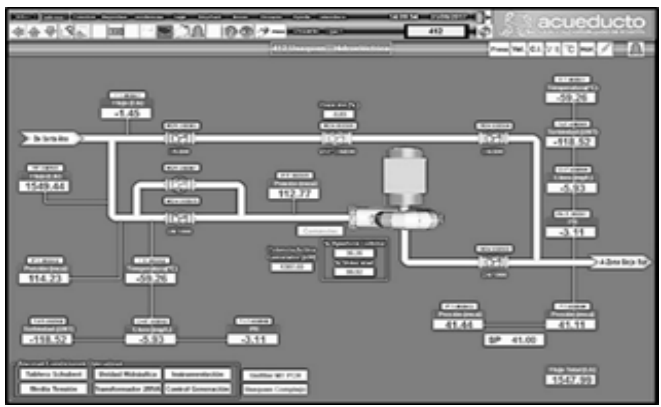

Figure 18. SCADA screen at the EAAB Control Center. Source: own.

The control philosophy is as follows: the system was designed with two modes of operation, automatic and manual in automatic mode the turbine, valves and switches are governed by a redundant Siemens S7 400 PLC, while in manual mode an operator must manipulate the elements locally through the HMI. The automatic operation can be by opening setpoint or pressure setpoint, where the turbine and multi-jet valve will operate according to the established value and its regulation is based on a PID controller. Depending on the pressure upstream and downstream, the maximum output power of the generator is reached in different percentages of opening of the turbine, so there is a PI regulator to limit the power.

To operate the turbine there must be no active fault messages, the main Codensa network must be energized and the gate valve downstream of the turbine must be open. When the start button is pressed, the turbine starts according to the following sequence: the brake is opened, the intake bypass valve opens completely to reduce the pressure difference between the butterfly valve and the turbine, the butterfly valve opens completely, the valve of the quick stop system of the hydraulic system is activated, the distributor opens continuously until reaching $90 \%$ of the nominal speed of the turbine, the PID control regulates the speed up to $100 \%$, at the same time the multi-jet valve is closed, the excitation control operates at $95 \%$ of the rated speed, the synchronization control operates at $98 \%$ of the nominal speed and sends the closing command of the machine breaker at the appropriate time [26].

\section{Investments and Budget}

The investment components included equipment, accessories and mechanical, electrical, control and supervision, instrumentation, communications and electromechanical services complementary to the station corresponding to the project. The adjustments, civil works, assemblies, installation and start-up of the infrastructure were also considered, as specified in Table $2[21]$.

\begin{tabular}{|l|l|}
\hline Item & $\begin{array}{c}\text { Direct Cost } \\
\text { [USD] }\end{array}$ \\
\hline Main equipment & \\
\hline machinery and accessories of the turbine & 932.001 \\
\hline electrical and control equipment of the turbine & 419.342 \\
\hline additional valves of the system & 272.272 \\
\hline Complementary equipment & \\
\hline pipes and accessories & 158.616 \\
\hline instrumentation, control and communications equipment & 270.153 \\
\hline Equipment and complementary electrical installations & 138.793 \\
\hline equipment for connection to power line & 129.575 \\
\hline Adjustments and civil works & \\
\hline Adjustments and various civil works & 217.003 \\
\hline total budget work & 2.537 .757 \\
\hline Administration, Unforeseens and Utilities (AUU) & $35 \%$ \\
\hline total Budget work with AUU & 3.425 .972 \\
\hline design and feasibility study & 419.450 \\
\hline connection contract to Codensa & 32.687 \\
\hline inspection & 376.608 \\
\hline total project investments & 4.254 .717 \\
\hline
\end{tabular}

Table 2. Project investments [21].

\section{Cost-Benefit}

The characteristics of the project have positive implications for the EAAB, such as: The economic income from the sale of the generated energy, the obtaining of bonuses granted due to the production of non-polluting energy and the mitigation of the company's carbon footprint. However, the incorporation of the new infrastructure associated with the project requires the allocation of additional resources for the operation and maintenance of the same $[21]$.

\subsection{Sale of Energy}

The energy delivered to the National Interconnected Network is registered in a commercial frontier meter and checked daily by the Compañía Americana Multiservicios (CAM) before the Administrator of the Commercial Interchange System (ASIC), to be communicated to interested parties for their analysis before being officially published on the XM website (ISA company in charge of managing the ASIC and the National Dispatch Center). The electricity generated is commercialized by EMGESA as representative of the plant before the Colombian wholesale energy market, according to regulations of the Energy and Gas Regulatory Commission(CREG). 
The gross potential income (without taking into account the costs and contributions payable) for the sale of the energy is obtained as the product of the sale rate for the generated energy. In the previous studies, possible scenarios were estimated for the sale of energy according to two tariff indicators: 1 . The stock price of the energy generators measured by the Unidad de Planeación Minero Energética (UPME) of the National Government, rate usually higher that that perceived by small power generators such as EAAB, 2 . The sale price of the energy generated in the HPP Santa Ana to EMGESA, which does not include discounts on bills for energy consumption that are provided by Codensa to the EAAB. Additionally, the average between these two rates was included as an indicator of the potential rate for project evaluation [21]. These tariff models are illustrated in Figure 19.

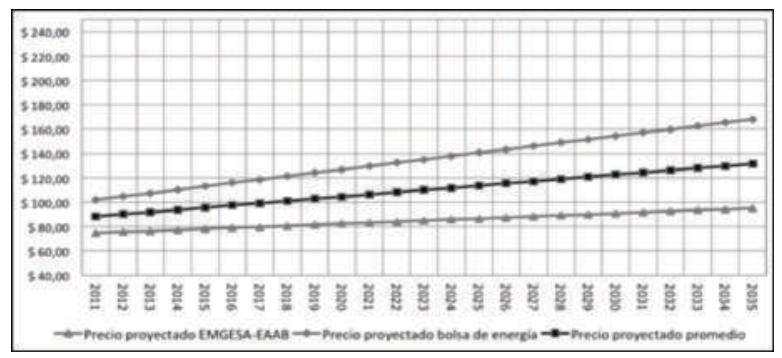

Figure 19. Tariff models projection at 2010 prices [20].

The projected cost-benefit analysis at 25 years, using the real interest rate of money raising from the financial system as a discount rate $(3.78 \%$ annual effective), resulted in the profitability of the capacity alternatives from 1.0 to 2.0 MW with any energy sale rate indicator for its positive Net Present Value (NPV) [20]. As an alternative for the cost-benefit analysis, the CRA discount rate of $13.34 \%$ (real discount rate before annual effective tax) was used, which indicated that the Usaquén HPP would be profitable for the 1.6 and 1.8 MW operational alternatives. with the average energy sale price. Additionally, it was concluded that the operational alternative of $1.8 \mathrm{MW}$ was the most favorable, due to the fact that its NPV in 2010 was higher than that presented by the other alternatives [20,21].

The adjusted annual generation for the installed capacity from 1.8 MW at $11.4 \mathrm{kV}$, delivered to Codensa at the terminals of the Usaquén substation was estimated at $12 \mathrm{GWh}$. However, the flow demanded by the southern low zone has decreased in the years of operation of the HPP (the maximum flow rate went from $2.72 \mathrm{~m} 3 / \mathrm{s}$ to $2.05 \mathrm{~m} 3 / \mathrm{s}$ ) leading to a proportional decrease in the energy generated. It should be noted that from the monthly invoiced value should be deducted taxes and contributions: to the Superintendencia de Industria y Comercio, to the Superintendencia de Servicios Públicos Domiciliarios, to the Centro Nacional de Despacho and to the Comisión Reguladora de Energía y Gas, in addition to penalties for start-ups and stops. Annual revenues for power generation from the start of the operation to December 2017 are shown in Table 3. Even when the generated energy has not reached what was established in the previous studies, the constant increase of the sale price of the $\mathrm{kWh}$, even above the most favorable projection, has compensated the income obtained.

\begin{tabular}{|l|l|l|l|l|}
\hline Year & $\begin{array}{l}\text { Generated } \\
\text { energy } \\
\text { [kWh] }\end{array}$ & $\begin{array}{l}\text { Mean } \\
\text { price kWh } \\
{[\$]}\end{array}$ & $\begin{array}{l}\text { Gross } \\
\text { income } \\
\text { [million \$] }\end{array}$ & $\begin{array}{l}\text { Net income } \\
\text { [million \$] }\end{array}$ \\
\hline 2013 & 5.281 & 129 & 712,92 & 677,26 \\
\hline 2014 & 8.915 & 138 & $1.248,68$ & $1.221,44$ \\
\hline 2015 & 9.060 & 147 & $1.334,89$ & $1.316,56$ \\
\hline 2016 & 6.780 & 202 & $1.391,49$ & $1.372,82$ \\
\hline 2017 & 8.442 & 192 & $1.615,82$ & $1.598,63$ \\
\hline total & 37.712 & & $6.303,82$ & $6.186,73$ \\
\hline
\end{tabular}

Table 3. Revenue by generated energy [27].

\subsection{Bonuses for Clean Energy Generation.}

The Usaquén HPP is framed in national policies in on issues related to the production of electric energy with renewable sources and technological innovation, in addition, it is consistent with the objectives established by the National Government related to the participation of Colombia in the KP through the implementation of CDM projects. In agreement with this, previous studies for the project estimated that Usaquén HPP would allow obtaining CERs by clean energy generation [20]. The EAAB assumed the costs and successfully surpassed all the phases of the cycle of a CDM project, which is divided into three main stages: 1) ex-ante: prefeasibility, feasibility, preparation of the Project Design Document (PDD), validation, national approval and registration; 2) execution and follow-up: operation and monitoring; 3) ex-post: verification and certification, issuance of CERs and sale or use of CERs obtained [5, $6,8,28]$.

The Usaquén and Suba HPPs were registered under the same CDM project No. 9798 on June 4, 2014, date from which their initial crediting period of 7 years begins, with the possibility of renewal for two more periods, 
that is, up to 21 years [29]. The GHG emission factor for small-scale projects is calculated annually by the Unidad de Planeación Minero Energética (UPME) with the AMS I.D methodology and adopted by resolution of the Ministerio de Minas y Energía [30-32]. Table 4 specifies the emission factor established and the annual GHG quantities reduced during the years of operation of the Usaquén HPP, taking into account that the energy produced there is not $100 \%$ clean because the HPP consumes electricity from the Codensa network for its operation, which causes discounts when calculating the reduction of GHG emissions.

\begin{tabular}{|l|l|l|l|}
\hline Year & $\begin{array}{c}\text { Generated } \\
\text { energy }[\mathrm{MWh}]\end{array}$ & $\begin{array}{l}\text { Emission factor } \\
{\left[\mathrm{tCO}_{2} \mathrm{eq} / \mathrm{MWh}\right]}\end{array}$ & $\begin{array}{c}\text { Reduced GHG } \\
{\left[\mathrm{tCO}_{2} \mathrm{eq}\right]}\end{array}$ \\
\hline 2013 & 5.281 & 0,374 & 1.755 \\
\hline 2014 & 8.915 & 0,388 & 2.103 \\
\hline 2015 & 9.060 & 0,401 & 3.453 \\
\hline 2016 & 6.780 & 0,367 & 2.584 \\
\hline 2017 & 8.442 & $\mathrm{n} / \mathrm{a}$ & 3.218 \\
\hline total & 37.712 & & 13.113 \\
\hline
\end{tabular}

Table 4. Reduced GHG [28, 33].

In the feasibility study of the project, considering the power generation described in the power and energy chapter, it was projected that the Usaquén HPP can provide the EAAB, from 2011 to 2020, an operational income for CERs bonds of 40,856 USD per year (values at 2010 prices) [21]. ICONTEC, as Designated Operational Entity (DOE) hired by the EAAB to carry out this audit process, requested the Executive Board of the CDM to issue 12,094 CERs (5,556 for the Usaquén HPP and 6,538 for the Suba HPP) corresponding to the verified period of June 4, 2014 to December 31, 2015, certificates that were granted on August 7, 2017 and of which the Executive Board of the CDM discounts $2 \%$, leaving 11,852 available.

In an auction held on February 12, 2018, 2300 CERs were sold, while in a second auction on March 13, 2018, another 1,722 certificates were commercialized, with which EAAB obtained revenues of $\$ 38,237,130$ in both processes. On the other hand, 1,577 CERs were used to neutralize the GHG emissions associated with the consumption of liquid fuels within the corporate carbon footprint of the EAAB, as well as obtaining significant savings due to the non-causation of the carbon tax established by Law 1819 of 2016 and that regulated Decree 926 of 2017 in Colombia, saving \$23,597,880 between November 2017 and March 2018 [29].

\section{Conclusions}

Despite the woldwide acceptance, the KP has limited potential whenever industrialized countries with a high percentage of emissions such as the United States, Japan and Russia do not accept it. On the other hand, the tendency in some developing countries has been to increase their emissions.

The KP, through flexible mechanisms such as the CDM, has converted $\mathrm{CO}_{2}$ into a tradable product and has promoted policies to mitigate climate change, however, it is not incentive enought for project developers, taking into account the low prices of the CERs and the limited period of certification for the projects, which is evidenced by the sale of the Santa Ana CERs at a price of $€ 16$ in 2008 versus the sale of Usaquén ones at $€ 7$ in 2018.

The Energy generated in the Usaquén HPP allowed the reduction of about $12,000 \mathrm{tCO}_{2} \mathrm{eq}$, ratifying the environmental commitment of the $\mathrm{EAAB}$. It is estimated that a regular gasoline car with a monthly consumption of 120 gallons can produce $12.8 \mathrm{tCO}_{2} \mathrm{eq} /$ year [5], which means that by the operation of the Usaquén HPP in a year, the emissions that can produce about 200 gasoline cars in the same period are reduced.

The policies and saving plans for optimizing water consumption in the city have caused a progressive decrease in the flow in the lower south zone, causing the Usaquén HPP not to reach the projections of power generation established in the previous studies, in fact, the year with the highest generation was 2015, where only $75.5 \%$ of the $12 \mathrm{GWh} /$ year expected was achieved.

Even when the generated energy has been lower than budgeted, the constant increase of the $\mathrm{kWh}$ Price in the national market, has compensated the income of the EAAB for energy sale.

The approximate cost of the project was $\$ 7,600$ million and since its entry into operation in May 2013 until December 2017, it has generated $38 \mathrm{GWh}$, reported income of nearly $\$ 6,000$ million thanks to the sale of energy.

\section{Acknowledgements}

This article was made possible thanks to the information provided by the Empresa de Acueducto $\mathrm{y}$ Alcantarillado de Bogotá - EAAB, especially thanks to the collaboration of the Dirección de Servicios de Electromecánica and the Dirección de Saneamiento Ambiental. 


\section{References}

[1] International Energy Agency (IEA), "CO2 emissions from fuel combustion highlights", 2017, pp. 9-10. [Online]. Available at: https://www.iea.org/publications/freepublica tions/publication/CO2EmissionsfromFuelCo mbustionHighlights2017.pdf.

[2] Naciones Unidas, "Protocolo de Kyoto de la convención marco de las Naciones Unidas sobre el cambio climático", 1998. [Online]. A v a i l a ble a t : https://unfccc.int/resource/docs/convkp/kps pan.pdf.

[3] A. L. Bernal, "Introducción a los proyectos MDL”, Revista Mundo Eléctrico, vol. 20, no. 64, 2006, pp. 1692-7052.

[4] J. A. Gracia, "La entrada en vigencia del protocolo de Kyoto y su importancia para el mundo", Revista Mundo Eléctrico, vol. 20, no. 64, 2006, pp. 13-14.

[5] M. P. Cruz and J. C. Sánchez, "Proyectos MDL de generación hidroeléctrica en la Empresa de Acueducto y Alcantarillado de Bogotá”, Revista Mundo Eléctrico, vol. 24, no. 80, 2010, pp. 20-26.

[6] N. Espinosa and W. Vanegas, "Análisis y evaluación de los beneficios que se pueden obtener en el mercado de la reducción de emisiones dentro del protocolo de Kyoto para la industria panelera en los departamentos Boyacá y Santander", thesis, Universidad Distrital Francisco José de Caldas, Bogotá, Colombia, 2008, pp. 14-18.

[7] D. F. Manotas, "Evaluación de proyectos de generación eléctrica bajo incertidumbre en política climática”, Revista Entramado, vol. 9, no. 1, 2013, pp. 102-117.

[8] Redacción Revista Mundo Eléctrico, "MDL: Instrumento económico para beneficio ambiental”, Revista Mundo Eléctrico, vol. 20, no. 64, 2006, pp. 15-20.

[9] Redacción El Tiempo, "Primera empresa pública de Colombia certificada por la ONU en reducción de gases contaminantes", 2007. [ $\mathrm{On} l \mathrm{ine}$ ]. A vail a ble a t : http://www.eltiempo.com/archivo/document o/MAM-2631894.
[10] Redacción El Espectador, "Bogotá estrena central hidroeléctrica para generar energía limpia”, 2015. [Online]. Available at: https://www.elespectador.com/noticias/bogo ta/bogota-estrena-central-hidroelectricagenerar-energia-l-articulo-560279.

[11] I. F. Florian and G. A. Castaño, "Formulación de una metodología para la evaluación expost de pequeñas centrales hidroeléctricas, caso: central hidroeléctrica de Santa Ana con componente MDL", thesis, Universidad Distrital Francisco José de Caldas, Bogotá, Colombia, 2010.

[12] Congreso de la República, "Ley 164 de 1994", Bogotá, Colombia. [Online]. Available at: http://www.secretariasenado.gov.co/senado/ basedoc/ley 0164 1994.html.

[13] Congreso de la República, Ley 629 de 2000, Bogotá, Colombia. [Online]. Available at: http://www.secretariasenado.gov.co/senado/ basedoc/ley_0629_2000.html.

[14] Ministerio de Ambiente, Vivienda y Desarrollo Sostenible, "Documento CONPES 3242", 2003. [O n line ]. Ava i l a ble a t : http://www.minambiente.gov.co/images/nor mativa/conpes/2003/Conpes_3242_2003.pdf.

[15] Ministerio de Ambiente, Vivienda y Desarrollo Sostenible, "Resolución 0340 de 2005", Bogotá, Colombia. [Online]. Available at: http://www.minvivienda.gov.co/Resoluciones Vivienda/0340\%20-\%202005.pdf.

[16] Ministerio de Ambiente, Vivienda y Desarrollo Sostenible, "Resolución 2734 de 2010", Bogotá, Colombia. [Online]. Available at: http://www.minambiente.gov.co/images/nor mativa/app/resoluciones/99res 2734 dic 2010.pdf.

[17] Secretaria Distrital de Ambiente, "Resolución 6524 de 2011", Bogotá, Colombia. [Online]. A v a i l a b le a $t$ : https://www.alcaldiabogota.gov.co/sisjur/nor mas/Norma 1.jsp? $\mathrm{i}=45452$.

[18] Empresa de Acueducto y Alcantarillado de Bogotá, "Manual de Operación de la Red Matriz de Bogotá", Bogotá, Colombia, 2013.

[19] J. C. Sánchez and A. I. Cadena, "Condiciones técnicas, económicas y regulatorias de 
aprovechamientos hidroeléctricos en el sistema de acueducto de Bogotá", Revista Mundo Eléctrico, vol. 20, no. 64, 2006, pp. 36-44.

[20] Consorcio Generación Bogotá, "Informe de capacidad de la PCH Usaquén”, Informe para la EAAB, Bogotá, Colombia, 2010.

[21] Consorcio Generación Bogotá, "Informe de factibilidad de la PCH Usaquén”, Informe para la EAAB, Bogotá, Colombia, 2010.

[22] Empresa de Acueducto y Alcantarillado de Bogotá, "Organigrama Institucional", 2018. [O n l i n e ]. A vail a ble a t : https://www.acueducto.com.co/wps/html/re sources/2017LPV/Organigramas/ORGANI GRAMA GENERAL.pdf.

[23] Consorcio Generación Bogotá, "Informe de diseño de la PCH Usaquén”, Informe para la EAAB, Bogotá, Colombia, 2010.

[24] Gugler Water Turbines GmbH, "Documentación Técnica, Operación y Mantenimiento, Turbina proyecto Usaquén", Bogotá, Colombia, 2010.

[25] S. Sangal, A. Garg and D. Kumar, "Review of Optimal Selection of Turbines for Hydroelectric Projects", International Journal of Emerging Technology and Advanced Engineering, vol. 3, no. 3, 2013, pp. 424-430.

[26] Consorcio Generación Bogotá, "Manual de operación PCH Usaquén”, Informe para la EAAB, Bogotá, Colombia, 2013.

[27] J. C. Sánchez, "Informe de energía generada", Informe para la EAAB, Bogotá, Colombia, 2018.

[28] Redacción Revista Mundo Eléctrico, "Portafolio MDL en Colombia", Revista Mundo Eléctrico, vol. 24, no. 80, 2010, pp. 6-10.

[29] M. P. Cruz, "Proyectos de reducción de emisiones de GEI de la Empresa de Acueducto, Alcantarillado y Aseo de Bogotá”, 2018. [Online]. Available at: https://www.acueducto.com.co/wps/html/resour ces/2018ag/huella_carbono/Proyectos_Reduccion Emisiones_GEI_21_02_2018.pdf.

[30] Redacción Revista Mundo Eléctrico, "Los proyectos energéticos están a la vanguardia en Colombia”, Revista Mundo Eléctrico, vol. 20, no. 64, 2006, pp. $21-23$.

[31] I. Concha, "Metodología simplificada para el cálculo de la linea base para proyectos de pequeña escala”, Revista Mundo Eléctrico, vol. 20, no. 64, 2006, pp. 30-33.

[32] Banco Interamericano de Desarrollo, "Metodología MDL de pequeña escala para Generación con Energía Renovable conectada a la Red “, 2011. [Online]. A v a i l a ble a t : http://finanzascarbono.org/comunidad/mod/file /download.php?file_guid=2189.

[33] Ministerio de Minas y Energía, "Resolución 9 1304 de 2014", Bogotá, Colombia. [Online]. Available at: https://diariooficial.vlex.com.co/vid/resolucion-numero-91304-546346914. 